\title{
Knowledge and Attitude Regarding Ill Effects of Substance Use Among School Going Children, Golaghat
}

\author{
Boby Begam ${ }^{1}$, Kabita Devi ${ }^{2}$ \\ ${ }^{1}$ Nursing Tutor (M.Sc. Psychiatric Nursing) ${ }^{2}$ Principal (M.Sc. Community Health Nursing) \\ VKNRL School of Nursing, Ponka Grant, Bishnupur Numaligarh, 785699, Assam, India
}

Corresponding Author: Boby Begam

\begin{abstract}
Adolescent starts with early healthy teens and ends up with the many unhealthy issues if not taken care of One of the high risk health issues of adolescence is related to substance use. It is a decade ago worldwide problem where India too has fallen into this viscous cycle. It has not only affected the health of adolescence but has also affected the future of the entire nation.
\end{abstract}

Objectives: The study aimed to find out knowledge and attitude on ill effects of substance use among school going children.

Material and Methods: The study adopted cross sectional descriptive design. The study was conducted in three School of Golaghat, Assam for a period of 2 weeks among 265 school going children who were selected using purposive sampling technique after taking the consent. Tool knowledge questionnaire related Substance Use and Attitude scale related Substance Use was used.

Results: It was found that $94 \%$ of the school going children was having high knowledge level on the ill effects of substance use and their attitude varies towards the substance use. There was no significant association found between knowledge score and selected socio demographic variable.

Conclusion: It was found that even after having sufficient knowledge and negative attitude towards the substance use, many adolescent are trapped in this phenomena. It may be because of lack of assertiveness and weaken coping ability of the adolescence.

Keywords: Knowledge, Attitude, Substance use, School Going Children

\section{INTRODUCTION}

Adolescence is a transitional stage of a young group of people between the ages of 10 to 19 years. Though according to World Health Organization the adolescents, are often thought as a healthy population but many serious issues in adulthood have their roots in adolescence. One of the issues is related to substance use. ${ }^{[1]}$ It is a phase when the mind is naturally motivated to experimentation and the first initiation of substance use usually takes place during adulthood. Substance use includes tobacco, alcohol, non-prescription pharmaceutical medications, narcotics and other addictive substances. $^{\text {[2] }}$

Increasing cases of substance use is associated with many factor like encouragement by peer groups, the lure of popularity, availability of drugs, changing cultural values, increasing economic stress, dwindling supportive bonds etc. ${ }^{[2-3]}$

Earlier initiation of drug use is found to have more impairment, crime, difficult to quit and is also associated with accidents, violence, high risk sexual behavior, interpersonal problems, decline in academic performance etc. ${ }^{[4-5]}$ The rising worldwide phenomenon of drug abuse among the younger generation has been causing great public concern. It not only affects the health and lives of individuals but also undermines the political, social, and cultural foundation of all countries. ${ }^{[3,6]}$ Through various surveys it is found that initiation of substance use 
has affected the comprehensive health of the adolescence and their family which in turn hampers the development of country. So the researcher investigated to study the substance use phenomenon with objective to know the knowledge and attitude on ill effects of substance use among school going children.

\section{MATERIALS AND METHODS}

This study was cross sectional descriptive study conducted in three high schools with 265 School going children of classes of VIII, IX, and X who were selected by purposive sampling technique in Golaghat School, Assam from $22^{\text {nd }}$ December 2020 to $30^{\text {th }}$ December 2020 after obtaining permission from respective school authority. A self structured questionnaire was administered after getting the informed verbal consent. Tools used in the study were tool I for socio-demographic variables and Tool II for knowledge questionnaire related Substance Use which is a check list for assessing the knowledge on ill effects of substance use with "Yes and No" as option. Tool III was for Attitude scale related Substance Use which is 3 point Likert scale for assessing attitude towards substance use with Option "Agree, Don't Know and Disagree." Ethical consideration was followed by maintaining confidentiality of information obtained and the respondents willingly participated in the survey.

\section{Statistical analysis}

The data were analysed using the Statistical Package for the Social Sciences statistical software (SPSS-18). The descriptive data related to socio demographic variable was calculated. The knowledge score was categorized into low, moderate and high knowledge level score. Frequency distribution was calculated for Attitude scale and the association between knowledge score and selected socio demographic variable was calculated.

\section{RESULTS}

Present study was conducted among 265 school going children and the findings of the study were group into three sections. Section I: Depicts frequency distribution of socio demographic variable of school going children. Study shows mean age of the children was 15.06. \pm 1.21 . Table 1 shows $63 \%$ of female school going children participated in the study out of which $40 \%$ were from class $9^{\text {th }}$ standard. $94 \%$ of them belong to rural area and $97 \%$ of them were staying with their family. $30 \%$ of the children got knowledge about Substance use from the School.

Table 1: Socio demographic profile of participants

\begin{tabular}{|c|c|c|c|c|}
\hline SIno & Variable & Categories & Frequency & Percentage $(\%)$ \\
\hline \multirow[t]{2}{*}{1} & \multirow[t]{2}{*}{ Gender } & Male & 97 & 37 \\
\hline & & Female & 168 & 63 \\
\hline \multirow[t]{3}{*}{2} & \multirow[t]{3}{*}{ Class } & $8^{\text {th }}$ & 95 & 35 \\
\hline & & $9^{\text {th }}$ & 103 & 40 \\
\hline & & $10^{\text {th }}$ & 67 & 25 \\
\hline \multirow[t]{4}{*}{3} & \multirow[t]{4}{*}{ Religion } & Hindu & 230 & 87 \\
\hline & & Islam & 22 & 8 \\
\hline & & Christian & 8 & 3 \\
\hline & & Others & 5 & 2 \\
\hline \multirow[t]{2}{*}{4} & \multirow[t]{2}{*}{ Type of family } & Nuclear & 202 & 76 \\
\hline & & Joint & 63 & 24 \\
\hline \multirow[t]{2}{*}{5} & \multirow[t]{2}{*}{ Domicile } & Rural & 249 & 94 \\
\hline & & Urban & 16 & 6 \\
\hline \multirow[t]{6}{*}{6} & \multirow[t]{6}{*}{ Source of knowledge about substance abuse } & School & 80 & 30 \\
\hline & & Friends & 23 & 9 \\
\hline & & Parents & 25 & 9 \\
\hline & & Television & 44 & 17 \\
\hline & & Internet & 37 & 14 \\
\hline & & Don't know & 56 & 21 \\
\hline \multirow[t]{3}{*}{7} & \multirow[t]{3}{*}{ Type of stay } & With family/ Relatives & 258 & 97 \\
\hline & & Hostel/ PG & 3 & 1 \\
\hline & & With Friends & 4 & 2 \\
\hline \multirow[t]{2}{*}{8} & \multirow[t]{2}{*}{ Does anyone in your family consume alcohol or smoke cigarette? } & Yes & 102 & 38 \\
\hline & & No & 163 & 62 \\
\hline
\end{tabular}


Boby Begam et.al. Knowledge and attitude regarding ill effects of substance use among school going children, Golaghat

\begin{tabular}{|c|c|c|c|c|}
\hline \multicolumn{5}{|c|}{ Table no. 1 continued..... } \\
\hline \multirow{4}{*}{9} & \multirow[t]{4}{*}{ No. of siblings } & One & 101 & 38 \\
\hline & & Two & 92 & 35 \\
\hline & & Three or four & 63 & 24 \\
\hline & & None & 9 & 3 \\
\hline \multirow[t]{6}{*}{10} & \multirow[t]{6}{*}{ Parents education } & Primary & 91 & 34 \\
\hline & & Secondary & 60 & 23 \\
\hline & & Diploma & 26 & 10 \\
\hline & & Graduate & 29 & 11 \\
\hline & & Post Graduate & 4 & 1 \\
\hline & & Illiterate & 55 & 21 \\
\hline
\end{tabular}

SECTION II: depicts the frequency distribution of knowledge level. Fig 1 shows $94 \%$ of school going children were having high knowledge level on ill effects of substance use whereas $1 \%$ of them were having low knowledge level.

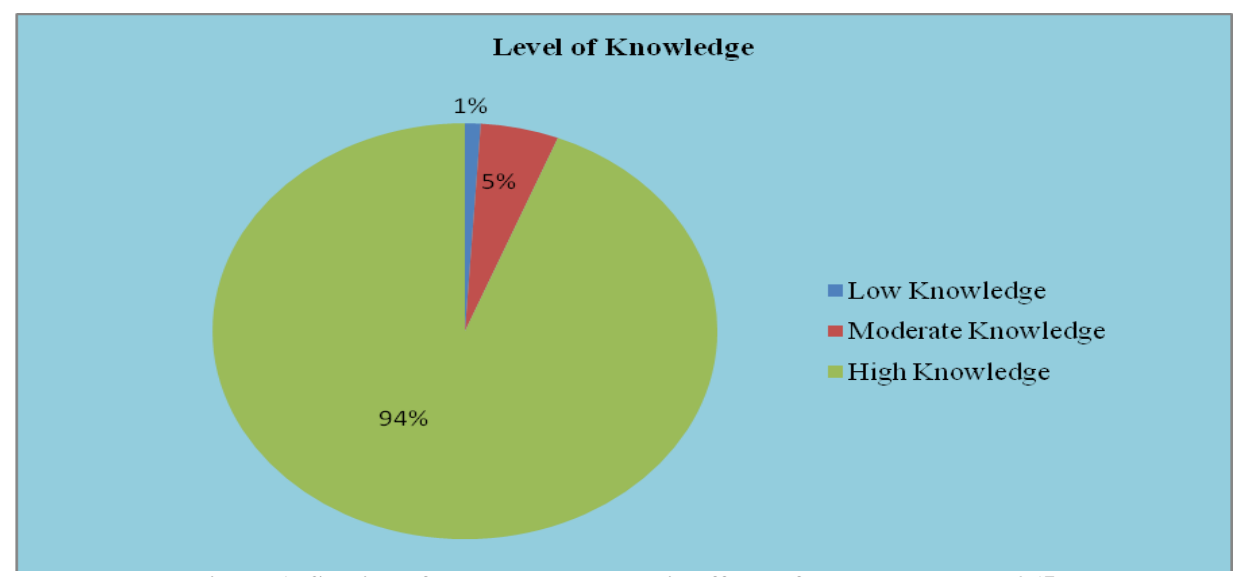

Figure 1: Scoring of knowledge level on ill effects of substance use $\mathrm{N}=265$

Section II: depicts frequency distribution of attitude of school going children towards substance use. It is found that school going children have varied attitude towards substance use.

Table 2: Attitude of school going children towards Substance Use

\begin{tabular}{|c|c|c|c|c|}
\hline Slno. & \multicolumn{2}{|l|}{ Attitude of school going children towards Substance Use } & Frequency & Percentage (\%) \\
\hline \multirow[t]{3}{*}{1} & \multirow[t]{3}{*}{ Risk of substance use increases if person is staying with such people } & Agree & 150 & 57 \\
\hline & & Disagree & 81 & 30 \\
\hline & & Don't Know & 34 & 13 \\
\hline \multirow[t]{3}{*}{2} & \multirow{3}{*}{ Females wont consume any substance } & Agree & 71 & 27 \\
\hline & & Disagree & 139 & 52 \\
\hline & & Don't Know & 55 & 21 \\
\hline \multirow[t]{3}{*}{3} & \multirow[t]{3}{*}{ There is no problem in substance intake until it is revealed to others } & Agree & 97 & 37 \\
\hline & & Disagree & 111 & 42 \\
\hline & & Don’t Know & 57 & 21 \\
\hline \multirow[t]{3}{*}{4} & \multirow{3}{*}{$\begin{array}{l}\text { Youth takes substances only when there is any quarrel between } \\
\text { parents/peers }\end{array}$} & Agree & 45 & 17 \\
\hline & & Disagree & 120 & 45 \\
\hline & & Don't Know & 100 & 38 \\
\hline \multirow[t]{3}{*}{5} & \multirow{3}{*}{$\begin{array}{l}\text { Substance abusing youth have no confidence to say "No" when somebody } \\
\text { offers them any substance. }\end{array}$} & Agree & 154 & 58 \\
\hline & & Disagree & 35 & 13 \\
\hline & & Don't Know & 76 & 29 \\
\hline \multirow[t]{3}{*}{6} & \multirow[t]{3}{*}{ Friends are the one who influence to take drugs } & Agree & 127 & 48 \\
\hline & & Disagree & 85 & 32 \\
\hline & & Don't Know & 53 & 20 \\
\hline \multirow[t]{3}{*}{7} & \multirow[t]{3}{*}{ Substance use is a social evil, not a disease } & Agree & 86 & 32 \\
\hline & & Disagree & 137 & 52 \\
\hline & & Don’t Know & 42 & 16 \\
\hline \multirow[t]{3}{*}{8} & \multirow{3}{*}{$\begin{array}{l}\text { Chances of substance taking behavior increases if there is a history of } \\
\text { family intake. }\end{array}$} & Agree & 154 & 58 \\
\hline & & Disagree & 62 & 23 \\
\hline & & Don't Know & 49 & 19 \\
\hline \multirow[t]{3}{*}{9} & \multirow[t]{3}{*}{ Easy availability of the substance cause of increase substance use. } & Agree & 189 & 71 \\
\hline & & Disagree & 21 & 8 \\
\hline & & Don’t Know & 55 & 21 \\
\hline \multirow[t]{3}{*}{10} & \multirow[t]{3}{*}{ Unemployment is a risk factor for substance abuse } & Agree & 48 & 18 \\
\hline & & Disagree & 118 & 45 \\
\hline & & Don't Know & 99 & 37 \\
\hline
\end{tabular}


Boby Begam et.al. Knowledge and attitude regarding ill effects of substance use among school going children, Golaghat

Section III: It shows the findings related to association between knowledge score and selected socio demographic variable. In the study it was found that there was no association between knowledge score and selected socio demographic variable

Table 3: Association between Knowledge score and selected socio demographic variable $\quad \mathrm{N}=265$

\begin{tabular}{|c|c|c|c|c|c|c|c|}
\hline \multirow{2}{*}{$\begin{array}{c}\text { Socio Demographic } \\
\text { Variable }\end{array}$} & \multirow[t]{2}{*}{ Categories } & \multicolumn{2}{|c|}{ Knowledge level } & \multirow{2}{*}{$\begin{array}{c}\text { Calculated } \\
\chi^{2}\end{array}$} & \multirow[t]{2}{*}{ df } & \multirow{2}{*}{$\begin{array}{c}P \\
\text { Value }\end{array}$} & \multirow[t]{2}{*}{ S/NS } \\
\hline & & $<15$ & $\geq 15$ & & & & \\
\hline \multirow[t]{2}{*}{ Gender } & Male & 25 & 72 & \multirow[t]{2}{*}{.128} & \multirow[t]{2}{*}{1} & \multirow[t]{2}{*}{.720} & \multirow[t]{2}{*}{ NS } \\
\hline & Female & 40 & 128 & & & & \\
\hline \multirow[t]{2}{*}{ Religion } & Hindu & 56 & 174 & \multirow[t]{2}{*}{.031} & \multirow[t]{2}{*}{1} & \multirow[t]{2}{*}{.835} & \multirow[t]{2}{*}{ NS } \\
\hline & Others & 9 & 26 & & & & \\
\hline \multirow[t]{2}{*}{ Years of education } & $8^{\text {th }}$ & 32 & 63 & \multirow[t]{2}{*}{6.7} & \multirow[t]{2}{*}{1} & \multirow[t]{2}{*}{.012} & \multirow[t]{2}{*}{$\mathrm{NS}$} \\
\hline & $9^{\text {th }}$ and $10^{\text {th }}$ & 33 & 137 & & & & \\
\hline \multirow[t]{2}{*}{ Types of family } & Nuclear & 48 & 155 & \multirow[t]{2}{*}{.365} & \multirow[t]{2}{*}{1} & \multirow[t]{2}{*}{.613} & \multirow[t]{2}{*}{ NS } \\
\hline & Joint & 17 & 45 & & & & \\
\hline \multirow[t]{2}{*}{ Domicile } & Urban & 63 & 186 & \multirow[t]{2}{*}{1.331} & \multirow[t]{2}{*}{1} & \multirow[t]{2}{*}{.37} & \multirow[t]{2}{*}{ NS } \\
\hline & Rural & 2 & 14 & & & & \\
\hline \multirow[t]{2}{*}{ Type of stay } & With Family & 64 & 194 & \multirow[t]{2}{*}{0.47} & \multirow[t]{2}{*}{1} & \multirow[t]{2}{*}{0.52} & NS \\
\hline & Hostel / Friends & 1 & 6 & & & & \\
\hline Parents occupation & Salaried & 14 & 43 & .000 & 1 & 1 & $\mathrm{NS}$ \\
\hline & Not salaried & 51 & 157 & & & & \\
\hline Education of Parents & Formal education & 13 & 41 & .008 & 1 & 1 & NS \\
\hline & No formal education & 52 & 159 & & & & \\
\hline
\end{tabular}

\section{DISCUSSION}

In the present study it was found that mean age of the school going children was $15.06 \pm 1.21$ which is similar with the study by Sharma I et al ${ }^{[1]}$ where mean age was 15 \pm 1.22. Majority of the school going children were female in the present study which concurs with the study by Adibelli D et al ${ }^{[7]}$ and Azima $S$ et al ${ }^{[8]}$ where $70.6 \%$ and 55 out of 90 were female. Present study showed rural population (94\%) is more than that of urban population $(6 \%)$ which is contrast with the study by Tsering $\mathrm{D}$ et $\mathrm{al}^{[9]}$ where urban population is more, that is $69.2 \%$. Present study showed $76 \%$ of participants were having nuclear family which is evident in other study by Gupta $S$ et $\mathrm{al}^{[10]}(80.5 \%)$; Smriti S et al ${ }^{[11]}(83.4 \%)$; Prakash $\mathrm{O}$ et al ${ }^{[5]}$ (two third); Dibya $\mathrm{T}$ et al ${ }^{[12]}$ (51\% )and Adibelli D et al ${ }^{[7]}(77.7 \%)$. Majority of participants were Hindu by religion which is similar to the study by Smriti S et al ${ }^{[11]}$ (49.6\%); Sharma I et al ${ }^{[1]}$ (59\%); Dibya T et al (66\%) ${ }^{[12]}$ and Rawat VS et al ${ }^{[13]}(68 \%)$. Majority of the respondents got the information about substance use from school which is evident in the study by Sharma I et al ${ }^{[1]}$ were majority of the respondents got the information about bad health effects of smoking from school teachers (38\%). A study by Shashidhar A et al ${ }^{[14]}$ found the contrast result to the present study where majority of participants had never been taught about smoking either in school or at homes and more than half obtained information about smoking from TV. In present study majority of the students said that there is no history of substance intake in their family which is consistent with the study by Dibya $\mathrm{T}$ et al ${ }^{[12]}$ were majority (77\%) of the adolescent students were not having history of any substance use in their family.

The high level knowledge (94\%) of schools going children on ill effects of substance use was comparable with the other study. Tsering D et al; ${ }^{[9]}$ Nebhinani N et al ${ }^{[4]}$; Masibo RM et al ${ }^{[15]}$ found majority of the respondents reported having adequate knowledge about the harm of substance use. Dibya $\mathrm{T}$ et al ${ }^{[\mathbf{1 2}]}$; Masih $\mathrm{OZ}$ et al ${ }^{[16]}$ and Ong'ang'o, Jane ${ }^{[17]}$ revealed most of the students had good knowledge that is $54 \%$, $82.03 \%$ and $72.4 \%$ respectively. Few research studies were found to be contrast to these findings that is by Paul L et al ${ }^{[18]}$ where knowledge of adolescents regarding alcoholism was found to be inadequate since $58 \%$ of them had just average level of knowledge.

In the present study children agree with the following cause for increase substance intake that are Influence of 
friends, availability of the substance, quarrel between parents/peer, unemployment and low confidence to say "No" which is also evident in the other study. Studies by Tsering D et al; [9] Sharma I et al ${ }^{[1]}$; Shashidhar A et al ${ }^{[14]}$ and Sahu KK et al ${ }^{[19]}$ cited peer pressure is one of the influencing factors of substance use. Sydow K et al ${ }^{[24]}$ found that easy availability of the substance increases substance use. Barkin SL et al ${ }^{\text {[21] }}$ found that peer pressure and low confidence level influences the adult to take substance. Geramian $\mathrm{N}$ et al ${ }^{[22]}$; Shamsi $\mathrm{MA}$ et al; Sydow $\mathrm{K}$ et al ${ }^{[23]}$ and Sydow $\mathrm{K}$ et al ${ }^{[24]}$ cited peer pressure, drugs availability, family/friends conflict, low confidence level and unemployment as the cause to start substance use. In the present study majority of the student disagree that Substance use is a social evil, not a disease which is contrast with the findings of the study by Prakash $\mathrm{O}$ et al ${ }^{[5]}$, where student agree with the substance use to be a disease.

In the present there was no significant association found between the knowledge score with selected socio demographical variable which is contrast to the present study by Dibya $\mathrm{T}$ et al ${ }^{[12]}$ where there was significant association between the awareness score and selected socio-demographic variable.

\section{CONCLUSION}

Substance use is a decade old problem of the society which has affected our youngster from many years and various studies has been done on this problem. The current study found that school going children have adequate knowledge about substance use and their attitude varies towards substance use. Even after having significant knowledge about the substance, adolescence has failed to overcome with this problem.

\section{Recommendation}

There should be provision to plan school health program to educate the students about substance use, stress management, relaxation technique and assertive training to investigate effectiveness of interventional program. Parents should also be involved in the educational programs.

\section{Acknowledgement: None}

Conflict of Interest: None

\section{Source of Funding: None}

\section{Ethical Approval: Approved}

\section{REFERENCES}

1. Sharma I and Chalise S. The Knowledge and Attitude Regarding the Health Effect of Smoking among Secondary Level Students in Nepal. Asian Journal of Humanities and Social Studies. 2018; 6(2): 83-90

2. Adolescents in India: A desk review of existing evidence and behaviours, programmes and policies. New Delhi: Population Council \& UNICEF; 2013

3. Sharma B, Arora A, Singh K et al. Drug abuse: Uncovering the burden in rural Punjab. Journal of Family Medicine and Primary Care. 2017; 6(3): 558-562

4. Nebhinani N, Mamta, Misra AK, et al. Knowledge and attitude about substance use in school students. Indian Journal of Social Psychiatry, 2013; 29 (3-4): 114-118

5. Prakash O, Giri OP, Mishra AK, et al. Knowledge and attitude of Indian adolescents towards addiction: Findings from an exploratory survey. Journal of Mental Health \& Human Behavior, 2009; 14 (2) : 74-79

6. Silas Treveli M and Seeta Devi A. A study to assess the knowledge and attitude of drug addiction among adolescent boys in selected pre-university colleges in Pune. International Journal of Recent Scientific Research. 2016; 7(5): 11293-11295

7. Adibelli D and Olgun S. Knowledge, Attitude and Behavior of Health College Students Related to Drug Abuse. The Ulutas Medical Journal. 2016; 2(2): 90-100

8. Azima S, Mousavi $S$ and Azima $M$. Students' Knowledge and Attitude about Factors, Treatment, and Prevention of Addiction in Higher Education Environments. International journal of current microbiology and applied sciences. 2015;4(10): 96-100 
9. Tsering $\mathrm{D}$, Pal $\mathrm{R}$ and Dasgupta A. Substance use among adolescent high school students in India: A survey of knowledge, attitude, and opinion. Journal of Pharmacy and Bioallied Sciences. 2010; 2: $137-40$

10. Gupta S, Sarpal SS, Kumar D et al. Prevalence Pattern and Familial Effects of Substance Use Among the Male College Students-A North Indian Study Journal of Clinical and Diagnostic Research. 2013; 7(8): 1632-1636

11. Smriti S, Divakar SV, Suryanarayana SP, et al. Prevalence of substance abuse among high school students in field practising area of Dr. B. R. Ambedkar Medical College, Bengaluru. International Journal of Community Medicine and Public Health. 2018; 5: 4423-6

12. Divya T, Radhakrishnan G and Chithra SA. The level of awareness and attitude on illeffects of substance abuse among adolescent students in selected high schools at Belgaum district, India. International Journal of Health Sciences \& Research. 2018; 8(3): 199-205

13. Rawat VS. A Study to Assess Knowledge and Attitude among Late Adolescents towards Alcoholism in Selected Colleges at Udaipur (Rajasthan). Journal of Drug Delivery and Therapeutics. 2019; 9(4-s): 1141-1143

14. Sashidhar A, Harish J and Keshavamurthy SR. Adolescent Smoking: A Study of Knowledge, Attitude and Practice in High School Children. Paediatric Oncall Journal. 2011; 8(1): 1-2

15. Masibo1 RM, Mndeme E and Nsimba DES. An assessment of knowledge, attitudes and practices of psychoactive substance use among secondary school students in Dodoma Municipality, Tanzania. American Journal of Research Communication. 2013; 200-240

16. Masih OZ, Hussain M, Afzal M, et al. Knowledge, Attitudes and Beliefs Regarding Drug Abuse among Male of Rural Community, Lahore, Pakistan.
International Journal of Social Sciences and management. 2019; 6(1): 1-6

17. Jane O. Knowledge, attitude and practice on substance use among high school students in Nairobi, Kenya. 2001;

18. Paul L and Ramya KR. Knowledge and Attitude towards Aloholism among Adolescents. Asian Journal of Nursing Education and Research. 2012; 2(4):212214

19. Sahu Kk1and Sahu S.2 Substance abuse causes and consequences. Bangabasi Academic Journal. 2012; 9: 52-59

20. Kodjo CM KJ. Prevention and risk of adolescent substance abuse. The role of adolescents, families, and communities. Pediatric Clinics of North America. 2002; 49: $257-268$

21. Barkin SL, Smith KS and DuRant RH. Social skills and attitudes associated with substance use behaviors among young adolescents. Journal of Adolescent Health. 2002; 30: 448-54

22. Geramian N, Akhavan S, Gharaat L, et al. Determinants of Drug Abuse in High School Students and their Related Knowledge and Attitude. Journal of pure and applied microbiology. 2012; 62(1): 62-66

23. Shamsi MA, Ziaeddini $H$ and Yazdi AS. Opinion of high school students of Kerman towards affecting factors on narcotics tendency (2005). Journal of Qazvin University of Medical Sciences. 2008;12(3): 80-88

24. Sydow KS, Lieb R, Pfister Ha, et al. What predicts incident use of cannabis and progression to abuse and dependence? A 4year prospective examination of risk factors in a community sample of adolescents and young adults. Drug and Alcohol Dependence. 2002; 68: 49-64

How to cite this article: Begam B, Devi K. Knowledge and attitude regarding ill effects of substance use among school going children, Golaghat. International Journal of Science \& Healthcare Research. 2021; 6(2): 216-221. DOI: https://doi.org/10.52403/ijshr.20210439 